\title{
PENURUNAN JUMLAH KOLONI STREPTOCOCCUS MUTANS DALAM RONGGA MULUT OLEH EKSTRAK ETANOL KULIT DAUN LIDAH BUAYA
}

\author{
I Gusti Ketut Armiati \\ Bagian Konservasi Gigi, Fakultas Kedokteran Gigi, Universitas Mahasaraswati, Denpasar \\ armiatigstkt@yahoo.co.id
}

\begin{abstract}
Dental plaque is a soft deposit which is firmly attached to the tooth surface. Streptococcus, Staphilococcus, Lactobacillus, and filaments form bacteria are microorganisms that can often be isolated from caries lesions and inflammation of the oral mucosa. Chlorhexidine gluconate is one of the antimicrobial agents become the gold standard in dentistry for the prevention of dental plaque. The aims of this study is to determine the effectiveness of rinsing with aloe vera skin leaf extract (Aloe vera barbadensis miller) in reducing the number of Streptococcus mutans in the oral cavity. Experimental studies with randomized pretest-posttest control group design, involving 30 patients, were divided into three (3) groups: the negative control group were rinsed with distilled water, the positive control group were rinsed with chlorhexidine gluconate $0.2 \%$, and the treatment group were rinsed with $100 \%$ aloe vera leaves extract. After treatment, analyzed by One Way ANOVA it was found decrease the number of $S$. mutans bacteria colonies in the positive control group and the treatment group after treatment $(p<0.05)$. While the negative control group did not decrease significantly. The conclusions of this study is rinsing with 100\% aloe vera skin leaf extract decrease the number of Streptococcus mutans bacteria colonies by $55.57 \%$.
\end{abstract}

Keywords: aloe vera skin leaf extract, Streptococcus mutans bacteria

\section{PENDAHULUAN}

Bakteri sangat berperan pada proses terjadinya karies gigi dan peradangan mukosa mulut. Jumlah mikroorganisme tergantung pada kesehatan dan kebersihan mulut seseorang, sedangkan jenis bakterinya tergantung lokasi di dalam rongga mulut. Mikroorganisme yang sering diisolasi dari lesi karies dan peradangan mukosa mulut adalah bakteri Streptococcus, Staphilococcus, Lactobacillus dan bakteri bentuk filament. Diantara kelompok bakteri tersebut Streptococcus dan Staphilococcus paling sering ditemukan, sehingga dapat dikatakan bahwa bakteri ini sangat berperan sebagai penyebab karies gigi dan peradangan mukosa mulut, khususnya Streptococcus mutans. ${ }^{1}$

Streptococcus mutans termasuk flora normal rongga mulut merupakan bakteri Gram positif, bersifat fakultatif anaerob, berbentuk coccus (bulat), tersusun seperti rantai dan berperan penting dalam proses terjadinya karies. Bakteri ini termasuk phylum dari Firmicutes dan merupakan kelompok bakteri yang menghasilkan asam laktat dan pertama kali ditemukan pada tahun 1924 oleh J. Kilian Clarke., ${ }^{2,3}$

Streptococcus mutans merupakan bakteri yang memulai terjadinya pertumbuhan plak pada permukaan gigi. Asam yang dihasilkan terus-menerus melalui pemecahan substrat yang selalu tersedia, akan merubah lingkungan rongga mulut menjadi lebih asam ( $\mathrm{pH}$ 5,2 5,5), yang selanjutnya menyebabkan proses demineralisasi pada email sehingga terjadi karies. ${ }^{4,3}$

Berbagai tindakan dilakukan untuk mempertahankan kesehatan rongga mulut salah satunya adalah dengan menyikat gigi. Obat kumur yang digunakan sebelum atau sesudah menyikat gigi dapat dipertimbangkan sebagai tindakan tambahan untuk kesehatan rongga mulut dan mengurangi jumlah serta perlekatan bakteri dalam rongga mulut. Untuk menambah efektivitas dari obat kumur, zat-zat anti mikroba ditambahkan ke dalam obat kumur.

Obat kumur yang mengandung zat anti mikroba dapat digolongkan menjadi dua yaitu yang zat aktifnya berasal dari tumbuh-tumbuhan dan yang berbahan dasar Chlorhexidine. ${ }^{5}$ Chlorhexidine gluconate 0,2\% merupakan salah satu zat antimikroba yang menjadi gold standard dalam kedokteran gigi untuk pencegahan plak gigi. ${ }^{6}$ Konsentrasi yang lebih rendah tidak efektif untuk mengurangi mikroba dalam rongga mulut. Chlorhexidine tersedia sebagai asetat, glukonat dan garam hidroklorida. Chlorhexidine memiliki berbagai aktivitas terhadap kedua bakteri gram positif dan gram negatif. ${ }^{7}$

Chlorhexidine gluconate telah dilaporkan memiliki sejumlah efek samping lokal. Penggunaan jangka panjang obat kumur ini dapat mengakibatkan perubahan warna gigi,perubahan warna pada beberapa bahan restorative, perubahan warna pada dorsum lidah,ulserasi mukosa mulut dan parasthesia, pembengkakan kelenjar parotis unilateral atau bilateral dan peningkatan pembentukan kalkulus supra gingiva. Selain kekurangan obat kumur di atas, obat kumur yang mahal menyebabkan penggunaan bahan herbal menjadi alternatif dalam pengobatan bakteri rongga mulut. Salah satu tanaman herbal yang memiliki zat antibakteri adalah kulit daun lidah buaya (Aloe barbadensis Miller). ${ }^{8}$

Kulit daun lidah buaya menjadi salah satu alternatif bahan alami yang dapat dikembangkan sebagai bahan bahan anti bakteri. Tanaman ini bersifat antibakteri antiinflamasi, analgesic dan tidak tosik. Tanaman ini sampai saat ini merupakan salah satu dari 
sepuluh tanaman terlaris di dunia yang berpotensi untuk dikembangkan sebagai tanaman obat. ${ }^{9}$

Karies gigi adalah suatu penyakit jaringan keras gigi yaitu email, dentin dan sementum akibat aktivitas fermentasi karbohidrat oleh jasad renik. Tanda karies gigi adalah adanya demineralisasi jaringan keras gigi yang kemudian diikuti bahan organiknya. Penyakit ini menyerang permukaan gigi-geligi yang mengakibatkan kerusakan mahkota gigi dan apabila tidak dilakukan perawatan akan meluas ke pulpa dan dapat merusak seluruh mahkota gigi. ${ }^{10}$ Selanjutnya terjadi invasi bakteri dan kematian pulpa serta penyebaran infeksinya ke jaringan periapikal.

Proses karies terjadi disebabkan karena kemampuan spesifik yang dimiliki oleh bakteri menggunakan sukrosa untuk menghasilkan suatu produk ekstraseluler yang lengket yang disebut dextran. Produk ini berbasis polisakarida dengan perantaraan enzim dextransucrase (hexocyltransferase) yang memungkinkan bakteri-bakteri tersebut membentuk plak. Untuk menghasilkan asam laktat, Streptococcus mutans bersama-sama dengan Streptococcus sabrinus dan Lactobacillus, memainkan peran yang sangat penting melalui enzim glucansucrase. Asam yang dihasilkan terusmenerus melalui pemecahan substrat yang selalu tersedia, akan merubah lingkungan rongga mulut menjadi lebih asam (pH 5,2 - 5,5), menyebabkan terjadinya proses demineralisasi yang selanjutnya terjadi karies. $^{2,3}$

Streptococcus mutans adalah suatu bakteri Gram positif, bersifat fakultatif anaerob berbentuk coccus (bulat), tersusun seperti rantai. Streptococcus mutans selain menyebabkan karies gigi juga sebagai patogenesis dari penyakit cardiovaskuler tertentu. Bakteri ini terdeteksi sebanyak 68,6\% dari hasil ekstirpasi jaringan klep jantung dan $74,1 \%$ pada atheromathous plaque. ${ }^{11}$

Lidah buaya (Aloe vera) adalah tumbuhan yang sudah dikenal sejak ribuan tahun silam dan digunakan sebagai penyubur rambut, penyembuh luka dan untuk perawatan kulit. Tumbuhan ini dapat ditemukan dengan mudah di kawasan kering di Afrika dan Asia. Seiring dengan kemajuan ilmu pengetahuan dan teknologi,pemanfaatan tanaman lidah buaya semakin berkembang sebagai bahan baku industri farmasi, kosmetika, serta sebagai bahan makanan dan minuman kesehatan. ${ }^{11}$ Di Indonesia, lidah buaya dikenal karena kegunaannya sebagai tanaman obat untuk aneka penyakit. Tanaman ini menjadi semakin populer akhirakhir ini karena manfaatnya yang semakin luas. ${ }^{8}$

Kandungan zat aktif yang terdapat dalam lidah buaya meliputi monosakarida, polisakarida, asam aminoesensial dan non-esensial, antrakuinon, enzim, mineral, vitamin, protein, lignin, asam salisilat, saponin, sterol, tanin, magnesium laktat dan senyawa antiprostaglandin. ${ }^{12}$ Zat aktif yang bersifat antibakteri adalah antrakuinon, saponin dan tannin. Secara spesifik dilaporkan bahwa ekstrak lidah buaya (aloe vera) mengandung kandungan zat aktif yang mampu menghambat pertumbuhan bakteri Escherichia coli. Dengan kata lain dapat dikatakan bahwa lidah buaya sensitif sebagai antimikroba terhadap bakteri Escherichia coli. $^{12}$

Penelitian yang dilakukan oleh Isabela (2009), menyatakan bahwa ekstrak lidah buaya mampu menghambat pertumbuhan Pseudomonas aeruginosa secara in vitro. Penelitian Ariyanthi dkk. (2012) menyatakan bahwa ekstrak kulit daun lidah buaya (Aloe barbadensis Miller) mampu menghambat pertumbuhan bakteri Staphylococcus aureus ATCC 25923 dan Escherichia coli ATCC 25922. ${ }^{13}$

\section{BAHAN DAN METODE}

Bahan yang digunakan pada penelitian ini adalah: (1) Daun lidah buaya (Aloe vera) yang tua yaitu daun yang terletak paling bawah. (2) Bakteri Streptococcus mutans ATCC 35668. (3) Media isolasi dan numerisasi: agar Mueller-Hinton ditambah 5\% darah kambing untuk bakteri Streptococcus mutans .(4) Media TSH untuk refresh bakteri, Etanol 96\% untuk ekstraksi daun lidah buaya (Aloe vera), Bahan $\mathrm{NaCl}$ 0,9\% untuk membuat kekeruhan.

Rancangan penelitian adalah penelitian eksperimental dengan rancangan Randomized pretestpostest control group design. ${ }^{14}$ Pengumpulan data dilakukan di Bagian Ilmu Konservasi Gigi RSGM FKG Universitas Mahasaraswati Denpasar dan analisis sampel dilakukan di Laboratorium Mikrobiologi FK Universitas Udayana Denpasar.

Sampel dibagi menjadi 3 kelompok, yaitu kelompok kontrol positif, yaitu orang coba berkumur Chlorhexidine gluconate $0,2 \%$. Kelompok kontrol negatif yaitu orang coba berkumur akuades dan kelompok perlakuan yaitu orang coba berkumur ekstrak kulit daun lidah buaya konsentrasi $100 \%$. Besar sampel adalah 10 sampel setiap kelompok, sehingga jumlah total sampel secara keseluruhan menjadi 30 sampel.

Prosedur penelitian adalah orang coba berkumur selama 60 detik tanpa menelan dan hasil kumur dibuang. Sampel diambil menggunakan lidi kapas pada gigi bagian permukaan labial gigi insisif pertama kanan atas, permukaan labial gigi insisif pertama kiri bawah, permukaan bukal gigi molar pertama kanan atas, permukaan bukal gigi molar pertama kiri atas, permukaan lingual gigi molar pertama kiri bawah dan permukaan lingual gigi molar pertama kanan bawah.

Swab dilakukan sebelum dan sesudah perlakuan. Hasil swab dimasukkan ke media TSB dan dilakukan pembiakan pada media Mueller Hinton Blood. Hasil biakan dilihat setelah 24 jam dan dihitung jumlah jumlah koloni bakteri yang tumbuh. Penguijian bakteri dengan uji gram, uji katalase dan uji mannitol. Pengolahan data dilakukan menggunakan dengan uji one way anova.

\section{HASIL DAN PEMBAHASAN}

Analisis efek perlakuan diuji berdasarkan rerata bakteri Streptococcus mutans antar kelompok sesudah diberikan perlakuan berupa berkumur ekstrak kulit daun lidah buaya $100 \%$. Hasil analisis kemaknaan dengan uji One Way Anova disajikan pada Tabel 1 berikut. 
Tabel 1 Perbedaan rerata bakteri Streptococcus mutans antar kelompok sebelum dan sesudah berkumur ekstrak kulit daun lidah buaya $100 \%(n=10)$

\begin{tabular}{lllll}
\hline Klp. & \multicolumn{1}{c}{ Pre } & \multicolumn{1}{c}{ Post } & \multicolumn{1}{c}{$F$} & \multicolumn{1}{c}{ P } \\
\hline K (-) & $6114,80 \pm 2733,93$ & $3683,34 \pm 921,63$ & 7,64 & 0,002 \\
K (+) & $6062,67 \pm 2179,5$ & $1751,67 \pm 803,87$ & & \\
P & $5760,80 \pm 2297,79$ & $1636,67 \pm 923,05$ & & \\
\hline
\end{tabular}

Ket: (K-): berkumur akuades, $\mathrm{K}(+)$ : berkumur Chlorhexidine gluconate 0,2\%, P: Kelompok perlakuan: berkumur ekstrak kulit daun lidah buaya konsentrasi $100 \%$

Analisis kemaknaan dengan uji One Way Anova pada Tabel 1 di atas, menunjukkan bahwa nilai $F=$ 7,64 dan nilai $\mathrm{p}=0,002$. Hal ini berarti bahwa rerata bakteri Streptococcus mutans pada ketiga kelompok sesudah diberikan perlakuan berbeda secara bermakna $(\mathrm{p}<0,05)$.

Untuk mengetahui kelompok mana saja yang berbeda dilakukan Uji Least Significant Differencetest (LSD).

Tabel 2 Beda nyata terkecil bakteri streptococcus mutans sesudah perlakuan antar kelompok

\begin{tabular}{ccc}
\hline Klp & Kontrol (+) & Perlakuan \\
\hline Kontrol (-) & $0,001 *$ & $0,011^{*}$ \\
Kontrol (+) & & 0,299 \\
\hline
\end{tabular}

Ket: (K-): berkumur akuades, $\mathrm{K}(+)$ : berkumur Chlorhexidine gluconate $0,2 \%, \mathrm{P}$ : Kelompok perlakuan: berkumur ekstrak kulit daun lidah buaya konsentrasi $100 \%$

Berbeda bermakna

Uji Least Significant Difference-test (LSD) di atas menunjukkan hasil sebagai berikut. Rerata kelompok kontrol negatif berbeda bermakna dengan kelompok kontrol positif. Rerata kelompok kontrol negatif berbeda bermakna dengan kelompok perlakuan. Rerata kelompok kontrol positif tidak berbeda bermakna dengan kelompok perlakuan.

Perbedaan rerata kelompok kontrol (-) dan kelompok perlakuan yang tidak berbeda bermakna di atas disebabkan karena kulit daun lidah buaya bersifat antibakteri, antiinflamasi, dapat meredam rasa sakit, tidak tosik. ${ }^{9}$ Untuk membuktikan bahwa adanya senyawa aktif di dalam lidah buaya yang mengandung senyawa antibakteri, maka dilakukan uji identifikasi fitokimia terhadap ekstrak kulit daun lidah buaya. Senyawa antibakteri yang di uji identifikasi fitokimia antara lain flavonoid, saponin, tanin, antrakuinon, dan fenolat. Flavonoid merupakan senyawa turunan fenol yang terdapat pada tumbuhan yang larut dalam air dan dapat di ekstraksi dengan menggunakan etanol. Mekanisme kerja dari flavonoid dalam menghambat pertumbuhan bakteri, antara lain bahwa flavonoid menyebabkan terjadinya kerusakan permeabilitas dinding sel bakteri, mikrosom, dan lisosom. ${ }^{15}$

Saponin merupakan glikosida yang larut dalam air dan etanol, tetapi tidak larut dalam eter. Saponin bekerja sebagai antibakteri dengan mengganggu stabilitas membran sel bakteri sehingga menyebabkan sel bakterilisis, jadi mekanisme kerja saponin termasuk dalam kelompok antibakteri yang mengganggu permeabilitas membran sel bakteri, yang mengakibatkan kerusakan membran sel dan menyebabkan keluarnya berbagai komponen penting dari dalam sel bakteri yaitu protein, asam nukleat dan nukleotida. ${ }^{16}$

Antrakuinon merupakan suatu antimikroba yang berspektrum luas. Lidah buaya mengandung beberapa glikosida antrakuinon (aloin, aloe-emodin dan barbaloin). Aloe-emodin bersifat bakterisidal terhadap Sreptococcus mutans. Salah satu mekanismenya adalah dengan menghambat transfer elektron pada rantai pernapasan mitokondria. ${ }^{17}$ Fenolat merupakan senyawa turunan fenol. Mekanisme antimikroba pada senyawa fenolat terhadap bakteri yaitu senyawa fenol dan turunannya yang dapat mengubah sifat protein sel bakteri. ${ }^{18}$ Perubahan struktur protein pada dinding sel bakteri akan meningkatkan permeabilitas sel sehingga pertumbuhan sel akan terhambat dan kemudian sel menjadi rusak. ${ }^{19}$

Tanin merupakan salah satu zat aktif pada tumbuhan yang memiliki sifat antimikroba khususnya pada lidah buaya. Mekanisme tanin sebagai antibakteri adalah cara mendenaturasi protein sel bakteri, menghambat fungsi selaput sel (transpor zat dari sel satu ke sel yang lain) dan menghambat sintesis asam nukleat sehingga pertumbuhan bakteri dapat terhambat. ${ }^{20}$

Penelitian pendahuluan yang telah dilakukan oleh peneliti secara in vitro pada ekstrak kulit daun lidah buaya dengan konsentrasi 25\%, 50\%, 75\% dan $100 \%$ terhadap bakteri Streptococcus mutans terdapat zona hambat pada konsentrasi 50\%, 75\% dan $100 \%$. Pada konsentrasi $50 \%$ terdapat zona hambat dengan rata-rata diameter $11 \mathrm{~mm}$, pada konsentrasi $75 \%$ terdapat zona hambat dengan diameter rata-rata 14 $\mathrm{mm}$ dan $100 \%$ terdapat zona hambat dengan diameter rata-rata $15 \mathrm{~mm}$. Rata-rata diameter zona hambat untuk Clorhexidin $0,2 \%$ sebesar $17 \mathrm{~mm}$.

Lebih lanjut diketahui bahwa lidah buaya mengandung berbagai senyawa biologis aktif, seperti mannans asetat, polymanannans, antrakuinon, dan berbagai lektin. Lidah buaya juga mengandung sekitar 75 jenis zat yang telah dikenal bermanfaat dan lebih dari 200 senyawa lain yang membuatnya layak digunakan dalam pengobatan herbal. Daun lidah buaya sebagian besar berisi daging daun yang mengandung getah bening dan lekat. Sedangkan bagian luar daun berupa kulit tebal yang berklorofil. ${ }^{21}$ Di samping itu, lidah buaya mempunyai kandungan zat gizi yang diperlukan tubuh dengan cukup lengkap, yaitu vitamin A, B1, B2, B6, B12, C, E,choline, inositol, dan asam folat. Kandungan mineralnya antara lain terdiri dari kalsium, sodium, besi, Zinc, dan kromium ${ }^{8}$

Kandungan enzim-enzimnya antara lain amylase, catalase, cellulose, carboxypeptidase, carboxyhelolase dan brandykinase yang semuanya penting bagi metabolisme tubuh. Kandungan asam aminonya, yakni argine, asparagin, asparatic acid, analine, serin, valine, glutamat, threonine, glycine, lycine, yrozine, proline, histidine, leucine, dan isoliucine. $^{21}$

Zat yang bersifat antibakteri dari lidah buaya adalah Antrakuinon, Saponin, Tanin, Flavonoid, dan Fenolat. Antrakuinon dalam lidah buaya memiliki 
fungsi sebagai bahan laksatif, penghilang rasa sakit, mengurangi racun dan antibakteri. ${ }^{8}$ Antrakuinon merupakan suatu antimikroba yang berspektrum luas. Lidah buaya mengandung beberapa glikosida antrakuinon (aloin, aloe-emodin, dan barbaloin). Aloe- emodin bersifat bakterisidal terhadap Staphilococcus sp. Salah satu mekanismenya adalah dengan menghambat transfer elektron pada rantai pernapasan mitokondria. ${ }^{17}$

\section{SIMPULAN}

Dari hasil penelitian dan pembahasan dapat disimpulkan bahwa berkumur ekstrak kulit daun lidah buaya konsentrasi $100 \%$ dapat menurunkan jumlah koloni bakteri Streptococcus mutans dalam rongga mulut. Tidak ada perbedaan penurunan jumlah koloni bakteri Streptococcus mutans dalam rongga mulut antara berkumur dengan ekstrak kulit daun lidah buaya konsentrasi $100 \%$ dengan berkumur Chlorhexidine gluconate $0,2 \%$.

\section{UCAPAN TERIMAKASIH}

Terimakasih yang sebesar-besarnya penulis sampaikan kepada pembimbing yaitu, Dr. dr. Bagus Komang Satriyasa, M.Repro, dan Prof. dr. Ketut Tirtayasa, MS,AIF, atas bimbingannya untuk penelitian ini. Terima kasih juga kepada Kepala Laboratorium Mikrobiologi Klinik Fakultas Kedokteran Universitas Udayana. Atas kelangsungan penelitian ini.

\section{DAFTAR PUSTAKA}

1. Samaranayake, L. Essential Microbiology for Dentistry. Churchill Livingstone : Elsevier Limited ; 2006. Hal. 255-84

2. Biswas, S., dan Biswas, I. Role of VitAB, an $A B C$ Transporter Complex in Viologen Tolerance in Streptococcus mutans. Antimicrobial Agents and Chemotherapy. 2011; 55(4): 1460-9.

3. Vinogradov, A.M., Winston, M., Rupp, C.J., and Stoodley, P. Rheology of Biofilms Formed from the Dental Plaque Pathogen Streptococcus mutans. Biofilm 2004; 1: h. 49-56.

4. Argimõn, S., and Caufiled, P.W. Distribution of Putative Virulence genes in Streptococcus mutans Strain does not Correlate with Caries Experience. Journal of Clinical Microbiology 2011; 49(3) : 984-92.

5. Suryo, S. Patologi Gigi-Geligi : KelainanKelainan Jaringan Keras Gigi. Gadjah Mada University Press. Yogyakarta 1992. h. 245-48.

6. Parwani, S., Rajkumar N., Himasnhu. Comparative Evaluation of Anti-Plaque Efficacy of Herbal and 0,2\% Chlorhexidine Gluconate Mouthwash in a 4- day Plaque Re-Growth Study. Journal of Indian Society of Periodontology 2013;17 (1): h. 365-69.

7. Groppo, F. C., Bergamaschi, CC. and Cogo, K. Use of Phytotheraphy in Dentistry. Phytoteraphy Research. 2008:22, 993-8

8. Hartawan, E. Y., Sejuta Khasiat Lidah Buaya, Ed. Ke-1, Jakarta, Pustaka Diantara 2012. 11-7
9. Hartawan, E. Y., Sejuta Khasiat Lidah buaya, Ed ke-1, Jakarta, Pustaka Diantara 2012. 11-7.

10. Rosenberg, J.D. Dental Cavities. Article. (Serial Online). Available from: http://www.nlm.nih.gov/medlineplus/ency/ article/oo1055.htm. Accessed April 29, 2012

11. Nakano, K., Ianaba, H., Nomura, R., Nemoto, H., Takeda, M., Yoshioka, H., Matsue, H., and Takahashi, T. Detection of Cariogenic Streptococcus mutans in Extirpated Heart Valve and Atheromatous Plaque Specimens. Journal of Clinical Microbiology 2006; 44(9): 3313-7.

12. Kathuria N, Gupta N, Manisha, Prasad R, Nikita. Biologic effects of Aloe vera 2011. h. 53740.

13. Isabela,A. Pengaruh Ekstrak Lidah Buaya (aloe vera) terhadap Pertumbuhan Pseudomonas aeruginosa pada Pasien Osteomielitis Bangsal Cempaka Rumah sakit Ortopedi Prof.Dr.R.Soeharso Surakarta In Vitro. Tesis. UPT Perpustakaan Universitas Sebelas Maret. Solo 2009. h. 278-81.

14. Pocock , S. J. Clinical Trials A Practical Approach.England : Jhon Wiley and Sons Ltd. The Atrium, South Gate, Chichester, West Sussex 2008. h. 425-29.

15. Sabir, A., Aktivitas antibakteri flavonoid propolis Trigona sp terhadap bakteri Streptococcus mutans (in vitro), Majalah Kedokteran Gigi. (Dent. J.) 2005; 38. ( 3) 13541.

16. Darsana, I. G. O., Besung, I. N. K., dan Mahatmi, H., Potensi Daun Binahong (Anredera Cordifolia (Tenore) Steenis) dalam Menghambat Pertumbuhan Bakteri Escherichia Coli secara In Vitro, Indonesia Medicus Veterinus 2012; 1 ( 3), $337-51$.

17. Rahardja, F., Puradisastra, S., dan Angelin, A. , Aktivitas Antimikroba Gel Lidah Buaya (Aloe Vera L.) pada Acne Vulgaris yang Terinfeksi Staphylococcus sp. Secara In Vitro, JKM 2010;10 (1). h. 30-6.

18. Hidayaningtias, P., Perbandingan efek air seduhan daun sirih (Piper betle Linn) terhadap Streptococcus mutans pada waktu kontak dan konsentrasi yang berbeda. Tesis. Fakultas Kedokteran Universitas Diponegoro Semarang 2008.

19. Agustin, D. W. Perbedaan khasiat antibakteri bahan irigasi antara hydrogen peroksida 3\% dan infusum daun sirih $20 \%$ terhadap bakteri mix, Majalah Kedokteran Gigi. (Dent. J.), 2005; 38. ( 1) 45-7.

20. Bachtiar, S. Y., Tjahjaningsih, W., dan Sianita, N. Pengaruh ekstrak alga cokelat (Sargassum sp) terhadap pertumbuhan bakteri Escherichia coli, Journal of Marine and Coastal Science 2017; (1), $53-60$.

21. Nurmalina, R., Herbal Legendaris Untuk Kesehatan Anda, Jakarta, PT Elex Media Komputindo Kompas Jakarta 2012. 389-9 